\title{
TINDAK TUTUR DALAM PEMBELAJARAN BAHASA INDONESIA PADA KELAS VII SMP KARTIKA II-2 BANDAR LAMPUNG TAHUN PELAJARAN 2017/2018 \\ Speech Acts in Indonesian Language Learning in Class VII, Kartika II-2 Middle School Bandar Lampung 2017/2018 Lesson Year
}

\author{
Dedi Satriawan \\ Fakultas Ekonomi dan Bisnis Islam UIN Raden Intan Lampung \\ Jalan Letkol H. Endro Suratman No. 1 Sukarame, Kota Bandar Lampung, Indonesia \\ Pos-el: dedisatriawan@radenintan.ac.1d \\ (Diterima: 24 Mei 2019, disetujui: 31 Maret 2020)
}

\begin{abstract}
This study aims to identify, describe the use of lokusi speech acts, ilokusi, and perlokusi and describe deviations in the use of the principle of politeness and cooperation in the three types of speech acts on learning in the classroom using a descriptive-qualitative approach, so that speech acts are used and deviations of the principle of politeness and cooperation used by teacher and students in carrying out Indonesian language learning. This study uses descriptivequalitative research methods, namely by using content analysis techniques. This means that by using this method the data that has been recorded through sound and video recording media and through direct recording will be transcribed and analyzed, described and interpreted with the intended purpose then concluded. In analyzing data, a series of activities are carried out, namely: (1) data reduction; (2) data presentation; and (3) conclusion drawing. The results of the study show that the teacher always utters speeches that have the intent and purpose to stimulate students to think and act actively in learning Indonesian and if it is associated with the use of the principle of politeness and cooperation, then the teacher and students are sufficiently able to use lokusi speech acts, ilokusi, and perlokusi which are in accordance with the principle of politeness and cooperation.
\end{abstract}

Keywords: locutionary, ilocutionary, perlocutionary, principles of politeness, cooperation

\begin{abstract}
Abstrak
Penelitian ini bertujuan untuk mengidentifikasi; mendeskripsikan penggunaan tindak tutur lokusi, ilokusi, dan perlokusi; dan mendeskripsikan penyimpangan penggunaan prinsip kesantunan dan kerja sama dalam ketiga jenis tindak tutur tersebut pada pembelajaran di dalam kelas dengan menggunakan pendekatan deskripitif-kualitatif sehingga dapat diketahui tindak tutur yang digunakan dan penyimpangan-penyimpangan prinsip kesantunan dan kerja sama yang digunakan guru dan siswa dalam melaksanakan pembelajaran bahasa Indonesia. Penelitian ini menggunakan metode penelitian deskriptifkualitatif, yaitu dengan menggunakan teknik analisis isi. Artinya, dengan menggunakan metode ini data yang telah direkam melalui media perekam suara dan video serta melalui pencatatan langsung akan ditranskripsikan dan dianalisis, dideskripsikan, dan ditafsirkan dengan tujuan yang telah ditetapkan kemudian disimpulkan. Dalam menganalisis data dilakukan rangkaian aktivitas, yakni: (1) reduksi data; (2) penyajian data; dan (3) penarikan kesimpulan. Hasil penelitian menunjukkan bahwa guru selalu menyampaikan tuturan yang memiliki maksud dan tujuan untuk merangsang siswa-siswa berpikir dan bertindak secara aktif dalam pembelajaran bahasa Indonesia dan jika dihubungkan dengan penggunaan prinsip kesantunan dan kerja sama, maka guru dan siswa sudah cukup mampu menggunakan tindak tutur lokusi, ilokusi, dan perlokusi yang sesuai dengan prinsip kesantunan dan kerja sama.
\end{abstract}

Kata kunci: tindak tutur lokusi, ilokusi, perlokusi, prinsip kesantunan, kerjasama 


\section{Pendahuluan}

Di SMP Kartika II-2 Bandar Lampung Kelas VII Semester Genap Tahun Pelajaran 2017/2018 didapatkan masih banyak siswa yang kurang aktif dalam pembelajaran bahasa Indonesia atau kurang dapat menerima dan memahami materi pembelajaran bahasa Indonesia yang disampaikan oleh guru di dalam kelas. Lebih khusus lagi, peneliti menemukan pelanggaran-pelanggaran prinsip kesantunan dan prinsip kerja sama dalam penggunaan tindak tutur lokusi, ilokusi, maupun perlokusi. Permasalahan yang terjadi dapat terlihat pada sebuah percakapan, seperti yang diungkapkan guru kepada muridnya.

\section{Guru : "Hey, kamu! Ketua kelas kan? spidolnya habis."}

Siswa :"Di sekretaris Bu."

Kalimat tersebut di atas merupakan jenis tindak tutur ilokusi, yakni guru menyampaikan informasi bahwa spidol yang dipergunakan untuk menulis di papan tulis putih (white board) sudah habis dan meminta ketua kelas untuk mengambilkan spidol yang baru. Makna kalimat tersebut bersifat eksplisit, yaitu disampaikan secara tidak langsung. Jika dihubungkan dengan prinsip kesantunan, maka kalimat tersebut melanggar maksim kearifan, yakni guru menggunakan kalimat yang kurang santun, hal ini dapat dibuktikan dengan penggunaan frase "Hey, kamu!'. Seharusnya seorang guru dapat memberikan teladan kepada siswanya dalam penggunaan bahasa yang santun, misalnya "Nak, bisa bantu Ibu ambilkan spidol yang baru?" kalimat ini dirasa lebih santun dibandingkan dengan kalimat "Hey, kamu! Ketua kelas kan? spidolnya habis." Jika dilihat dari jawaban yang diberikan siswa, maka siswa tersebut sudah melanggar maksim kedermawanan. Maksim ini mewajibkan setiap peserta tindak tutur untuk memaksimalkan kerugian bagi diri sendiri dan meminimalkan keuntungan bagi diri sendiri. Ujaran yang disampaikan oleh siswa tersebut di atas dipandang kurang santun karena siswa tersebut berusaha memaksimalkan keuntungan bagi dirinya dengan menyusahkan orang lain (sekretaris) untuk memberikan spidol yang baru kepada gurunya.

Selain itu,jika dihubungkan dengan prinsip kerja sama, maka kalimat tersebut di atas melanggar maksim kualitas dan relevansi. Dilihat dari maksim kualitas, kalimat yang disampaikan guru tersebut dapat dikatakan melanggar karena guru mengatakan spidolnya habis. Secara kualitas, guru tersebut tidak mengatakan maksud ujarannya secara benar. Ia bermaksud untuk memberikan perintah kepada ketua kelas mengambilkan spidol yang baru, namun tidak dengan penggunaan kalimat yang benar. Seharusnya, guru tersebut menggunakan kalimat "Tolong ambilkan spidol yang baru." Tidak hanya itu, siswa yang memberikan jawaban atas pertanyaan guru tersebut juga telah melanggar maksim relevansi. Maksim relevansi mengharuskan setiap peserta percakapan memberikan kontribusi yang relevan dengan masalah pembicaraan, sedangkan yang terjadi pada percakapan di atas, siswa memberikan jawaban yang kurang relevan atas pertanyaan yang diberikan oleh gurunya. Hal ini mengimplikasikan bahwa saat itu ketua kelas tidak menyimpan spidol yang baru. Secara tidak langsung, ketua kelas tersebut meminta tolong kepada sekretarisnya untuk memberikan spidol yang baru kepada gurunya. Secara maksim relevansi, seharusnya siswa menjawab "Iya Bu, saya akan mengambilkan spidol yang baru."

Berdasarkan prapenelitian tersebut, masalah ini diduga disebabkan oleh tindak tutur yang dilakukan oleh guru dan siswa dalam pembelajaran bahasa Indonesia belum berjalan dengan baik, terutama saat percakapan (berbicara) antara guru dan siswa dengan adanya pelanggaran prinsip kesantunan dan kerja sama dalam penggunaan tindak tutur lokusi, ilokusi, dan perlokusi. Hal ini diduga disebabkan bahasa yang digunakan guru kurang dapat dipahami oleh siswa atau sebaliknya. Ketika guru menjelaskan materi pembelajaran atau memberi pertanyaan kepada 
siswa, siswa kurang memahami maksud tuturan dari guru tersebut.

Berdasarkan hasil pengamatan tersebut dirasa perlu dan menarik untuk membahas persoalan tersebut dalam penelitian yang berjudul "Tindak Tutur dalam Pembelajaran Bahasa Indonesia pada Kelas VIII SMP Kartika II-2 Bandar Lampung Tahun Pelajaran 2017/2018". Agar masalah penelitian dapat dipahami dengan mudah, maka pertanyaan penelitian dirumuskan sebagai berikut.

Bagaimanakah tindak tutur lokusi, ilokusi, dan perlokusi kaitannya dengan prinsip kesantunan dan kerja sama dalam pembelajaran bahasa Indonesia pada kelas VIII SMP Kartika II-2 Bandar Lampung Tahun Pelajaran 2017/2018?

Searle (dalam Wijana dan Rohmadi, 2010) mengemukakan bahwa secara pragmatis, setidaknya ada tiga jenis tindakan yang dapat diwujudkan oleh seorang penutur, yakni tindak lokusi (locutionary act), tindak ilokusi (ilocutionary act), dan tindak perlokusi (perlocutionary act).

Tindak lokusi adalah tindak tutur untuk menyatakan sesuatu. Tindak tutur ini sering disebut sebagai The Act of saying something. Sebagai contoh tindak lokusi adalah kalimat berikut.

1. Mamad belajar membaca,

2. Ali bermain piano.

Kedua kalimat di atas diutarakan oleh penuturnya semata-mata untuk menginformasikan sesuatu tanpa tendensi untuk melakukan sesuatu, apalagi untuk memengaruhi lawan tuturnya. Tindak lokusi merupakan tindakan yang paling mudah diindentifikasi karena dalam pengidentifikasian tindak lokusi tidak memperhitungkan konteks tuturannya.

Tindak ilokusi adalah tindak tutur yang berfungsi untuk mengatakan atau menginformasikan sesuatu dan dipergunakan untuk melakukan sesuatu. Tindak ilokusi disebut sebagai The Act of doing something dan kalimat berikut sebagai contoh.
3. Yuli sudah seminar proposal tesis kemarin. 4. Santoso sedang sakit.

Kalimat (3) jika diucapkan kepada seorang mahasiswa semester VI, bukan hanya sekadar memberikan informasi saja, akan tetapi juga melakukan sesuatu, yaitu memberikan dorongan agar mahasis-wa tadi segera mengerjakan tesisnya. Kalimat (4) jika diucapkan kepada temannya yang menghidupkan radio dengan volume tinggi berarti bukan saja sebagai informasi, tet-api juga untuk menyuruh agar mengecilkan volume atau mematikan radionya. Tindak ilokusi sangat sulit diidentifikasi ka-rena terlebih dahulu harus mempertimbangkan siapa penutur dan lawan tuturnya.

Tindak perlokusi adalah tindak tutur yang pengutaraan-nya dimaksudkan untuk memengaruhi lawan tuturnya. Tin-dak perlokusi disebut sebagai The Act of affecting someone. Sebuah tuturan yang diutarakan seseorang sering kali mempunyai daya pengaruh (perlocutionary force) atau efek bagi yang men-dengarnya. Efek yang timbul ini bisa sengaja maupun tidak se-ngaja.

Sebagai contoh dapat dilihat pada kalimat berikutini.

5. Kemarin ayahku sakit.

6. Samin bebas SPP.

Kalimat (5) jika diucapkan oleh sese-orang yang tidak dapat menghadiri undangan temannya, maka ilokusinya adalah untuk meminta maaf dan perlokusinva adalah agar orang yang mengundangnya maklum. Kalimat (6) jika diucapkan seorang guru kepada mu-rid-muridnya, maka ilokusinya adalah meminta agar teman-temannya tidak iri dan perlokusinya adalah agar teman-teman-nya memaklumi keadaan ekonomi orang tua Samin. Tindak perlokusi juga sulit dideteksi karena harus me-libatkan konteks tuturnya. Dapat ditegaskan bahwa setiap tutur dari seorang penutur memungkinkan sekali mengandung lokusi saja atau perlokusi saja. Namun, tidak 
tertutup kemungkinan bahwa satu tuturan mengandung kedua atau ketiganya sekaligus.

Pencetus teori tindak tutur, Searle (1975; lihat Gunarwan, 1994) membagi tindak tutur menjadi lima kategori: yaitu:(1) representative/ asertif, yaitu tuturan yang mengikat penuturnya akan kebenaran atas apa yang diujarkan; (2) direktif/impositif, yaitu tindak tutur yang dimaksudkan penuturnya agar si pendengar melakukan tindakan yang disebutkan di dalam tuturan itu; (3) ekspresif/evaluatif, yaitu tindak tutur yang dimaksudkan penuturnya agar ujarannya diartikan sebagai evaluasi tentang hal yang disebutkan dalam tuturan itu; (4) komisif, yaitu tindak tutur yang mengikat penuturnya untuk melaksanakan apa yang disebutkan di dalam tuturannya; dan (5) deklaratif/establisif/ isbati, yaitu tindak tutur yang dimaksudkan penuturnya untuk menciptakan hal (status dan keadaan) yang baru.

Wijana (1996) menjelaskan bahwa tindak tutur dapat dibedakan menjadi tindak tutur langsung dan tindak tutur tidak langsung serta tindak tutur literal dan tidak literal.

\section{Tindak tutur langsung dan taklangsung}

Secara formal berdasarkan modusnya, kalimat dibedakan menjadi kalimat berita (deklaratif), kalimat tanya (interrogatif), dan kalimat perintah (imperatif). Secara konvensional, kalimat berita (deklaratif) digunakan untuk memberitahukan sesuatu (informasi); kalimat tanya untuk menanyakan sesuatu; dan kalimat perintah untuk menyatakan perintah, ajakan, permintaaan atau permohonan. Apabila kalimat berita difungsikan secara konvensional untuk mengadakan sesuatu; kalimat tanya untuk bertanya; dan kalimat perintah untuk menyuruh, mengajak memohon dan sebagainya, maka akan terbentuk tindak tutur langsung (direct speech), contoh: Yuli merawat ayahnya. Siapa orang itu? Ambilkan buku saya! Ketiga kalimat tersebut merupakan tindak tutur langsung berupa kalimat berita, tanya, dan perintah.

Tindak tutur tak langsung (indirect speech act) ialah tindak tutur untuk memerintah seseorang melakukan sesuatu secara tidak langsung. Tindakan ini dilakukan dengan memanfaatkan kalimat berita atau kalimat tanya agar orang yang diperintah tidak merasa dirinya diperintah. Misalnya seorang ibu menyuruh anaknya mengambil sapu, diungkapkan dengan “Upik, sapunya dimana?" Kalimat tersebut selain untuk bertanya sekaligus memerintah anaknya untuk mengambilkan sapu.

2. Tindak tutur literal dan tindak tutur takliteral

Tindak tutur literal (literal speech act) adalah tindak tutur yang maksudnya sama dengan makna kata-kata yang menyusunnya. Tindak tutur tidak literal (nonliteral speech act) adalah tindak tutur yang maksudnya tidak sama dengan atau berlawanan dengan katakata yang menyusunnya. Sebagai contoh dapat dilihat kalimat berikut.

7. Penyanyi itu suaranya bagus.

8. Suaramu bagus (tapi kamu tidak usah menyanyi)

Kalimat (7) jika diutarakan dengan maksud untuk memuji atau mengagumi suara penyanyi yang dibicarakan, maka kalimat itu merupakan tindak tutur literal, sedangkan pada kalimat (8) penutur bermaksud mengatakan bahwa suara lawan tuturnya jelek, yaitu dengan mengatakan "Tak usah menyanyi”. Tindak tutur pada kalimat (8) merupakan tindak tutur takliteral. Apabila tindak tutur langsung dan tak langsung diinteraksikan dengan tindak tutur literal dan takliteral, maka akan tercipta tindak tutur sebagai berikut ini.

1) Tindak tutur langsung literal (direct literal speech act), ialah tindak tutur yang diutarakan dengan modus tuturan dan makna yang sama dengan maksud pengutaraannya. Maksud memerintah disampaikan dengan kalimat perintah, memberitakan dengan kalimat berita, dan menanyakan sesuatu dengan kalimat tanya, misalnya: Ambilkan buku itu! Kusuma gadis yang cantik. Berapa saudaramu, Mad? 
2) Tindak tutur tidak langsung literal (indirect literal speech act) adalah tindak tutur yang diungkapkan dengan modus kalimat yang tidak sesuai dengan maksud pengutaraannya, tetapi makna kata-kata yang menyusunnya sesuai dengan apa yang dimaksudkan oleh penutur, misalnya: "Lantainya kotor". Kalimat itu jika diucapkan seorang ayah kepada anaknya bukan saja menginformasikan, tetapi sekaligus menyuruhuntuk membersihkannya.

3) Tindak tutur langsung tidak literal (direct non literal speech) adalah tindak tutur yang diutarakan dengan modus kalimat yang sesuai dengan maksud dan tuturan, tetapi katakata yang menyusunnya tidak memiliki makna yang sama dengan maksud penuturnya, misalnya: "Sepedamu bagus, kok". Penutur sebenarnya ingin mengatakan bahwa sepeda lawan tuturnya jelek.

4) Tindak tutur tidak langsung tidak literal (indirect nonliteral speech act) adalah tindak tutur yang diutarakan dengan modus kalimat yang tidak sesuai dengan maksud yang ingin diutarakan. Untuk menyuruh seorang pembantu menyapu lantai kotor, seorang majikan dapat saja mengutarakannya dengan kalimat "Lantainya bersih sekali, Mbok".

Berdasarkan beberapa penjelasan para ahli tersebut di atas, penulis menggunakan pendapat Searle dan Austin yang membagi tindak tutur menjadi tiga jenis, yaitu tindak lokusi, tindak ilokusi, dan tindak perlokusi. (1) lokusi merupakan tuturan si penutur yang semata-mata hanya untuk menyampaikan informasi saja; (2) ilokusi merupakan tuturan si penutur yang mengharapkan tindakan dari mitra tuturnya; dan (3) perlokusi yaitu si penutur memberikan daya pengaruh atau efek kepada mitra tuturnya atau lawan bicaranya. Pendapat ini yang akan digunakan sebagai acuan untuk menjawab pertanyaan penelitian ini.

Berbicara tidak selamanya berkaitan dengan masalah yang bersifat tekstual, tetapi seringkali pula berhubungan persoalan yang bersifat interpersonal. Bila sebagai retorika tekstual pragmatik membutuhkan prinsip kerja sama, sedangkan sebagai retorika interpersonal pragmatik membutuhkan prinsip lain, yakni prinsip kesantunan. Prinsip kesantunan memiliki sejumlah maksim, yakni (1) maksim kearifan atau kebijaksanaan;(2) maksim kedermawanan atau penerimaan; (3) maksim pujian atau kemurahan; (4) maksim kerendahan hati; (5) maksim pemufakatan atau kecocokan; dan (6) maksim simpati (Wijana dan Rohmadi, 2009). Prinsip kesantunan berhubungan dengan dua peserta percakapan, yakni diri sendiri dan orang lain. Diri sendiri adalah penutur dan orang lain adalah lawan tutur dan orang ketiga yang dibicarakan penutur dan lawan tutur.

Maksim ini bermaksud agar setiap peserta pertuturan meminimalkan kerugian orang lain atau memaksimalkan keuntungan bagi orang lain. Dalam hal ini dapat dikatakan bahwa semakin panjang tuturan seseorang, semakin besar pula keinginan orang itu untuk bersikap santun kepada lawan bicaranya. Demikian pula tuturan yang diutarakan secara tidak langsung lazimnya lebih santun dibandingkan dengan tuturan yang diutarakan secara langsung. Memerintah dengan kalimat berita atau kalimat tanya dipandang lebih santun dibandingkan dengan kalimat perintah. Contoh:

Datang ke rumah saya! (tidak santun)

Jika tidak keberatan, sudilah Anda datang ke rumah saya. (santun)

Maksim kedermawanan atau penerimaan mewajibkan setiap peserta tutur untuk memaksimalkan kerugian bagi diri sendiri dan meminimalkan keuntungan bagi diri sendiri. Artinya, bila di dalam berbicara penutur berusaha memaksimalkan keuntungan orang lain, maka lawan bicara wajib pula memaksimalkan kerugian dirinya, bukan sebaliknya.

+ Boleh saya bawakan buku-bukunya, Bu?

- Tidak usah, Ibu bisa bawa sendiri kok.

Kalimat di atas lebih mematuhi maksim kearifan atau kebijaksanaan. Bandingkan dengan kalimat di bawah ini. 
+ Boleh saya bawakan buku-bukunya, Bu?

- Ini, gitu baru murid Ibu.

Kalimat di atas melanggar maksim kearfian atau kebijaksanaan karena si lawan tutur tidak memaksimalkan kerugian dirinya sendiri.

Maksim pujian atau kemurahan mewajibkan setiap peserta pertuturan untuk memaksimalkan rasa hormat kepada orang lain dan meminimalkan rasa tidak hormat kepada orang lain. Untuk jelasnya dapat dilihat pada wacana berikut.

+ Nilai Bahasa Indonesiamu sangat bagus.

- Tidak, saya kira biasa-biasa saja.

Bandingkan dengan wacana berikut. + Nilai Bahasa Indonesiamu sangat bagus. - Oh, tentu. Saya gitu lho!

Tokoh $(+)$ dalam wacana yang pertama bersikap sopan karena berusaha memaksimalkan keuntungan(-) lawan tuturnya. Lawan tuturnya (-) dalam wacana pertama mematuhi maksim pujian atau kemurahan dengan berusaha meminimalkan penghargaan untuk diri sendiri, sedangkan (-) dalam wacana yang kedua melanggar maksim pujian atau kemurahan karena berusaha memaksimalkan keuntungan diri sendiri. Jadi, tokoh (-) dalam wacana kedua tidak berlaku santun.

Maksim kerendahan hati menuntut setiap peserta pertuturan untuk memaksimalkan ketidakhormatan pada diri sendiri dan meminimalkan rasa hormat pada diri sendiri. Bila maksim kemurahan berpusat pada orang lain, maksim kerendahan hati berpusat pada diri sendiri. Contoh:

+ Kau sangat pandai.

- Ya, saya memang pandai.

Wacana di atas menunjukkan tokoh (-) melanggar maksim kerendahan hati. Berbeda dengan wacana berikutyang mematuhi maksim kerendahan hati.
+ Kau sangat pandai.

- Ah tidak, biasa-biasa saja. Itu hanya kebetulan.

Maksim kecocokan atau pemufakatan menggariskan setiap penutur dan lawan tutur untuk memaksimalkan kecocokan di antara mereka dan meminimalkan ketidakcocokan di antara mereka.

Contoh:
(1) + Bahasa Inggris susah, ya?
- Ya.
(2) + Bahasa Inggris susah, ya?
- Siapa bilang? Mudah sekali kok.

Kontribusi (-) dalam wacana pertama lebih sopan dibandingkan dengan wacana kedua karena dalam wacana kedua (-) memaksimalkan ketidakcocokannya dengan pernyataan $(+)$. Dalam hal ini, tidak berarti orang harus senantiasa setuju dengan pendapat atau pernyataan lawan tuturnya. Jika ia tidak menyetujui apa yang dinyatakan oleh lawan tuturnya, maka ia dapat membuat pernyataan yang mengandung ketidaksetujuannya atau ketidakcocokannya, seperti pada wacana berikut.

+ Bahasa Inggris susah, ya?

- Ya, tetapi tata bahasanya tidak begitu susah dipelajari.

Maksim kesimpatian ini mengharuskan setiap peserta petuturan untuk memaksimalkan rasa simpati dan meminimalkan rasa antipati kepada lawan tuturnya. Jika lawan tutur mendapatkan kesuksesan atau kebahagiaan, penutur wajib memberikan ucapan selamat. Bila lawan tutur mendapatkan kesusahan atau musibah, penutur layak turut berduka atau mengutarakan ucapan bela sungkawa sebagai tanda kesimpatian.

+ Aku lulus Ujian Nasional, Ded.

- Selamat ya! 
+Aku lulus Ujian Nasional, Ded.

- Pasti hasil nyontek ya!

Wacana pertama menunjukkan kepatuhan terhadap maksim simpati. Sebaliknya, pada wacana kedua (-) melanggar maksim simpati karena antipati kepada $(+)$ yang telah berhasil lulus ujian dengan memberikan pernyataan yang bisa saja menyinggung perasaan $(+)$.

Percakapan merupakan interaksi verbal antara dua partisipan atau lebih. Percakapan dalam hal ini lebih dari sekadar pertukaran informasi. Menurut Ismari (http:// jasminealmaghribi.blogspot.com), mereka yang mengambil bagian dalam proses percakapan tersebut akan memberikan asumsi-asumsi dan harapan-harapan mengenai percakapan sehingga percakapan tersebut berkembang sesuai dengan jenis kontribusi yang diharapkan dan telah dibuat oleh mereka. Mereka dalam hal ini akan saling berbagi prinsip-prinsip umum yang akan memudahkan dalam menginterpretasikan ujaran-ujaran yang dihasilkan.

Di dalam berkomunikasi, seorang penutur mengkomunikasikan sesuatu kepada petutur dengan harapan agar petutur itu dapat memahami apa yang dikomunikasikannya. Tidaklah mungkin akan terjadi komunikasi antara penutur dan petutur apabila antara keduanya tidak terjadi komunikasi. Oleh karena itu, seorang penutur harus selalu berusaha agar pembicaraannya itu relevan dengan konteks, jelas, mudah dipahami, padat dan ringkas, serta terfokus pada persoalan sehingga tidak menghabiskan waktu. Dengan kata lain, antara penutur dan petutur terdapat prinsip kerja sama yang harus mereka terapkan agar proses komunikasi dapat berjalan dengan lancar.

Kerja sama dapat diartikan sebagai keterlibatan partisipan dalam membentuk suatu percakapan lengkap dengan unsur-unsur yang diperlukan. Fungsi kerja sama adalah membentuk peristiwa tutur. Grice (1975) mengemukakan mengenai prinsip kerja sama:
Make your contribution such as is required at the stage at which it occurs, by the accepted purpose or direction of the talk exchange in wich you are engaged. "Berikanlah sumbangan Anda pada percakapan sebagaimana diperlukan, pada tahap terjadinya, oleh tujuan yang diterima atau arah pertukaran pembicaraan yang Anda terlibat di dalamnya." Pada umumnya, kerja sama dalam percakapan ditopang oleh unsur-unsurnya. Unsur-unsur penopang kerja sama dalam percakapan disebut sebagai maksim. Maksim merupakan petuah yang memberikan tuntunan dalam bertutur.

Penelitian ini menggunakan metode penelitian deskriptif-kualitatif, yaitu dengan menggunakan teknik analisis isi. Artinya dengan menggunakan metode ini, data yang telah direkam melalui media perekam suara dan video serta melalui pencatatan langsung akan ditranskripsikan dan dianalisis, dideskripsikan, dan ditafsirkan dengan tujuan yang telah ditetapkan kemudian disimpulkan. Dalam menganalisis data, dilakukan rangkaian aktifitas, yakni: (1) reduksi data; (2) penyajian data; dan (3) penarikan simpulan.

\section{Hasil dan Pembahasan}

Berikut akan diuraikan pembahasan terhadap temuan penelitian berupa kata, kalimat, paragraf yang dikutip dari tuturan pendidik dan peserta didik dalam pembelajaran bahasa Indonesia di dalam kelas yang terdiri atas tindak tutur lokusi, ilokusi, dan perlokusi. Setiap kalimat, paragraf, atau dialog yang mengandung jenis tindak tutur lokusi, ilokusi, dan perlokusi akan dimaknai sesuai dengan porsinya dan dianalisis relevansinya dengan penggunaan prinsip kesantunan dan kerja sama, apakah tuturan-tuturan tersebut mengandung penyimpangan-penyimpangan prinsip kesantunan dan kerja sama atau tidak dengan interpretasi peneliti.

Hasil pembahasan terhadap temuan penelitian adalah sebagai berikut. 


\subsection{Tindak Tutur Lokusi}

1. Guru : "Selamat siang anak-anak."

Siswa: "Siang Pak." (jawab murid serentak)

Tuturan guru di atas termasuk ke dalam jenis tindak tutur lokusi. Hal ini karena ketika guru mengucapkan tuturan tersebut hanya sebagai ucapan sapaan saja tanpa maksud tertentu kepada siswa untuk melakukan suatu perbuatan atau tindakan. Jika dihubungkan dengan prinsip kesantuan dan kerja sama, maka tuturan ini tidak mengalami penyimpangan apapun karena tuturan yang diucapkan sesuai dengan konteksnya dan dapat dikatakan tuturan yang santun.

2. Guru: "Nanti bapak begini, ada dua cerita yang awalnya sama, namun endingnya berbeda."

Siswa: "Iya pak."

Tuturan tersebut adalah tuturan yang termasuk dalam kategori jenis tindak tutur lokusi. Hal ini karena guru yang bersangkutan hanya menginformasikan bahwa Beliau memberikan contoh tentang dua cerita yang awalnya sama, namun akhir ceritanya berbeda. Guru tersebut tidak bermaksud untuk menginginkan siswa melakukan suatu perbuatan, melainkan hanya sekadar pemberian contoh tentang materi yang sedang disampaikan. Jika dilihat hubungan dengan penggunaan prinsip kesantuan dan kerja sama, maka tuturan ini tidak mengalami penyimpangan.

3. Guru: "Dalam mengembangkan cerita, kamu boleh menggunakan alur maju, mundur, atau campuran."

Siswa: "Tapi boleh cuma 1 paragraf ya Pak."

Tuturan tersebut di atas merupakan jenis tuturan lokusi. Hal ini karena guru hanya sebatas memberikan informasi kepada siswa bahwa saat mengerjakan tugas yang akan diberikan boleh menggunakan alur maju, mundur, atau campuran. Tepat dalam konteks tuturan tersebut, siswa tidak melakukan tindakan apapun karena hanya sebatas informasi saja.
Jika dilihat dari penggunaan prinsip kesantuan, maka tuturan di atas melanggar maksim kedermawanan. Mengingat pengertian dari maksim kedermawanan adalah meminimalkan keuntungan diri sendri dan memaksimalkan kerugian diri sendiri, maka jelas tuturan jawaban dari siswa tersebut telah melanggar maksim kedermawanan, yaitu hanya ingin mengerjakan tugas yang diberikan oleh guru sebatas satu paragraf saja. Padahal, idealnya dalam sebuah karangan harus terdiri atas beberapa paragraf.

\subsection{Tindak Tutur Ilokusi}

1. Guru :"Alur kemarin apa artinya?"

Siswa :"Jalannya cerita."

Tuturan tersebut di atas dapat dikatakan jenis tindak tutur ilokusi. Hal ini karena apa yang disampaikan oleh guru merupakan suatu pertanyaan yang menghendaki suatu perbuatan atau tindakan, yaitu jawaban dari apa yang ditanyakan. Dinilai dari prinsip kesantunan, maka tidak ada satu kata pun yang menunjukkan pelanggaran di dalamnya. Dari prinsip kerja sama pada tuturan atau jawaban yang disampaikan oleh siswa, maka kalimat tersebut sudah menaati maksim kuantitas dan kualitas. Kuantitas artinya jawaban yang diberikan siswa tidak melebihi apa yang dikehendaki oleh guru sebagai penanya, begitu juga dengan maksim kualita. Maka, kalimat yang dijadikan sebagai jawaban sudah mengenai sasaran dengan apa yang dikehendaki oleh guru. Oleh karena itu, kalimat tersebut di atas tidak mengandung palanggaran.

2. Guru :"Ada berapa jenis alur?"

Siswa: "Ada tiga."

Tuturan di atas adalah jenis tindak tutur ilokusi. Sama dengan kutipan sebelumnya, guru menyampaikan pertanyaan yang menghendaki jawaban dari siswanya. Begitu juga dengan prinsip kesantunan dan kerja sama. Dinilai dari prinsip kesantunan, maka tidak ada satu kata pun yang menunjukkan pelanggaran di dalamnya. Dari prinsip kerja sama, tuturan atau jawaban yang disampaikan oleh siswa, maka kalimat tersebut sudah menaati maksim 
kuantitas dan kualitas. Kuantitas artinyajawaban yang diberikan siswa tidak melebihi apa yang dikehendaki oleh guru sebagai penanya, begitu juga dengan maksim kualitas, maka kalimat yang dijadikan sebagai jawaban sudah mengenai sasaran dengan apa yang dikehendaki oleh guru. Oleh karena itu, kalimat tersebut di atas tidak mengandung palanggaran.

3. Guru : "Pertama apa tadi?"

Siswa :"Maju."

Tuturan tersebut di atas dapat dikatakan jenis tindak tutur ilokusi. Hal ini karena apa yang disampaikan oleh guru merupakan suatu pertanyaan yang menghendaki suatu perbuatan atau tindakan, yaitu jawaban dari apa yang ditanyakan. Dinilai dari prinsip kesantunan, maka tidak ada satu kata pun yang menunjukkan pelanggaran di dalamnya. Dari prinsip kerja sama, tuturan atau jawaban yang disampaikan oleh siswa, maka kalimat tersebut sudah menaati maksim kuantitas dan kualitas. Kuantitas artinya jawaban yang diberikan siswa tidak melebihi apa yang dikehendaki oleh guru sebagai penanya, begitu juga dengan maksim kualitas, maka kalimat yang dijadikan sebagai jawaban sudah mengenai sasaran dengan apa yang dikehendaki oleh guru. Oleh karena itu, kalimat tersebut di atas tidak mengandung palanggaran.

4. Guru :"Penokohan ada berapa?"

Siswa: "Ada tiga."

Tuturan tersebut di atas adalah jenis tindak tutur ilokusi. Sama dengan kutipan sebelumnya, guru menyampaikan pertanyaan yang menghendaki jawaban dari siswanya. Begitu juga dengan prinsip kesantunan dan kerja sama. Dinilai dari prinsip kesantunan, maka tidak ada satu kata pun yang menunjukkan pelanggaran di dalamnya. Dari prinsip kerja sama, tuturan atau jawaban yang disampaikan oleh siswa, maka kalimat tersebut sudah menaati maksim kuantitas dan kualitas. Kuantitas artinya jawaban yang diberikan siswa tidak melebihi apa yang dikehendaki oleh Guru sebagai penanya, begitu juga dengan maksim kualitas, maka kalimat yang dijadikan sebagai jawaban sudah mengenai sasaran dengan apa yang dikehendaki oleh guru. Oleh karena itu, kalimat tersebut di atas tidak mengandung palanggaran.

5. Guru :"Doni, apa? Selain antagonis?"

Doni : "Protagonis."

Tindak tutur dalam kutipan tersebut di atas merupakan tindak tutur jenis ilokusi karena merupakan sebuah pertanyaan dari seorang guru kepada seorang siswa yang menghendaki jawaban. Selain itu, dilihat dari penggunaan prinsip kesantunan, maka tidak terjadi pelanggaran. Dari penggunaan prinsip kerja sama, terjadi pelanggaran maksim kuantitas. Hal ini karena jawaban yang seharusnya tidak hanya protagonis saja, melainkan tritagonis juga. Artinya pelanggaran yang terjadi adalah kurang lengkapnya jawaban yang diberikan oleh siswa.

6. Guru : "Kemudian amanat, apa?"

Siswa : Pesan cerita."

Sama halnya dengan kutipan yang sebelumnya, kutipan tersebut di atas merupakan jenis tindak tutur ilokusi karena Guru yang bertanya nmenghendaki jawaban atas pertanyaannya tersebut. Secara penggunaan prinsip dan kerja sama, kutipan ini tidak mengandung pelanggaran.

7. Guru : "Dari tiga ini yang akan kita pelajari, jika ada pertanyaan, silahkan."

Siswa: (diam)

Tindak tutur yang terjadi di dalam kutipan tersebut di atas merupakan tindak tutur ilokusi karena guru bermaksud untuk memberikan kesempatan kepada siswa dalam melakukan suatu perbuatan atau tindakan, yaitu bertanya tentang suatu hal yang kurang mereka pahami. Jika dilihat dari penggunaan prinsip kesantunannya, maka respons yang diberikan siswa adalah respons yang melanggar maksim kedermawanan. Terbukti dengan adanya respons siswa yang mengabaikan perintah guru untuk menanyakan suatu hal yan tidak jelas atau tidak mereka pahami. Hal ini sesuai dengan pengertian maksim kedermawanan, yaitu 
meminimalkan keuntungan diri sendiri dan memaksimalkan keuntungan orang lain. Padahal, seharusnya jika guru memberikan kesempatan siswa untuk bertanya, maka siswa harusnya bertanya agar segala sesuatu yang belum mereka pahami dapat menemukan jawaban dan mereka tidak akan mengalami kesulitan dalam mengerjakan tugas yang akan diberikan.

\section{Guru : "Bagi kelompok, satu kelompok dua orang." \\ Hasfran: "Kalau sendiri gimana, Pak?"}

Kutipan tersebut di atas adalah jenis tindak tutur ilokusi. Hal ini karena guru menghendaki siswa untuk bertindak, yaitu membagi kelompok di dalam kelas. Jika dilihat dari penggunaan prinsip kesantunan, maka terjadi pelanggaran maksim kerendahan hati dalam kalimat jawaban yang disampaikan oleh siswa yang bernama Hasfran. Adapun pengertian dari maksim kerendahan hati adalah memaksimalkan ketidakhormatan diri sendiri, sedangkan yang terjadi, Hasfran berusaha menyombongkan dirinya bahwa dengan sendiri ia mampu melakukan tugas yang akan diberikan oleh guru. Selain itu, dilihat dari penggunaan prinsip kerja sama, maka kalimat yang disampaikan oleh Hasfran merupakan kalimat yang melanggar maksim kualitas. Hal ini disebabkan jawaban yang diberikan oleh Hasfran bukanlah jawaban yang dikehendaki oleh guru.

\subsection{Tindak Tutur Perlokusi}

\section{Guru: "Sangkuriang, Aris? Apa amanat yang bisa kamu ambil?"}

Aris : "Gak boleh cinta sama ibunya sendiri." Tian: "Hahaha, iya lah.. aneh."

Kutipan tersebut di atas adalah kutipan yang masuk dalam kategori jenis tindak tutur perlokusi karena ada akibat atau efek dari apa yang telah dikatakan oleh Aris. Efeknya terjadi pada Tian yang menjawab secara spontan tentang apa yang disampaikan oleh Aris karena hal ini dirasa lucu menurut Tian. Jika dilihat dari penggunaan prinsip kesantuan, maka kalimat yang disampaikan oleh Tian mengandung pelanggaran pada maksim pujian, yaitu mencemoohkan jawaban Aris, atau dengan kata lain Tian meminimalkan rasa hormatnya pada Aris. Dari penggunaan prinsip kerja sama, maka dalam kalimat yang disampaikan Aris mengandung pelanggaran maksim kualitas, yaitu jawaban yang diberikan oleh Aris bukanlah yang dikehendaki oleh gurunya.

2. Guru : "Ya, Bapak tambah nilai 20."

Siswa: "Beeh.. enak amat geh."

Tuturan tersebut di atas adalah jenis tindak tutur perlokusi karena apa yang disampaikan oleh guru mengakibatkan efek tertentu, yaitu jawaban salah satu siswa yang timbul akibat apa yang disampaikan oleh gurunya. Jika dilihat dari penggunaan prinsip kesantunannya, maka kalimat yang disampaikan oleh siswa tersebut melanggarmaksim simpati, yaitu meminimalkan rasa hormat kepada gurunya sendiri.

3. Guru :"Ada yang memberi komentar?"

Sinta : "Tambah 20 juga ya, Pak?"

Kutipan tersebut di atas adalah jenis tindak tutur perlokusi karena apa yang disampaikan oleh guru menimbulkan suatu efek yang membuat siswa bereaksi atas apa yang disampaikan oleh gurunya. Hal ini terbukti dari efek atau reaksi yang terjadi pada kalimat yang disampaikan oleh Sinta bahwa ia sangat tertarik untuk memberikan komentar, namun dengan iming-iming tambahan nilai dari gurunya. Jika dilihat dari penggunaan prinsip kesantunannya, maka kalimat yang diucapkan oleh Sinta mengandung pelanggaran pada maksim kedermawanan, yaitu memaksimalkan keuntungan dirinya sendiri. Selain itu, jika dilihat dari penggunaan prinsip kerja sama, maka Sinta telah melanggar maksim kualitas dan relevansi. Melanggar maksim kualitas karena Sinta menjawab yang tidak benar dengan pertanyaan yang diberikan oleh guru. Pelanggaran maksim relevansi yaitu Sinta memberikan jawaban yang tidak sesuai atau tidak relevan dengan pertanyaan yang diberikan gurunya. 
4. Guru :"Bagaimana ceritanya?"

Medi: "Pak, pernah baca di internet."

Kutipan tersebut di atas adalah jenis tindak tutur perlokusi karena apa yang disampaikan oleh guru menimbulkan suatu efek yang membuat siswa bereaksi dari apa yang disampaikan oleh gurunya. Hal ini terbukti dari efek atau reaksi yang terjadi pada kalimat yang disampaikan oleh Medi bahwa ia pernah membaca di internet cerita yang dibuat oleh temannya. Dengan kata lain, Medi bereaksi dengan tujuan memberitahukan bahwa cerita yang dibuat temannya tidaklah asli, melainkan menjiplak di media internet. Jika dilihat dari penggunaan prinsip kesantunannya, maka kalimat yang diucapkan oleh Medi mengandung pelanggaran pada maksim pujian, yaitu meminimalkan rasa hormat kepada temannya yang membuat cerita. Selain itu, jika dilihat dari penggunaan prinsip kerja sama, maka Sinta telah melanggar maksim kualitas dan relevansi. Ujaran Sinta melanggar maksim kualitas karena Medi menjawab yang tidak benar dengan pertanyaan yang diberikan oleh guru. Pelanggaran maksim relevansi yaitu Medi memberikan jawaban yang tidak sesuai atau tidak relevan dengan pertanyaan yang diberikan guru.

5. Guru : "Bapak ada tugas buat minggu depan, cari sebuah cerpen dari majalah, lalu kamu gunting dan tempel."

Siswa: "Pak, diprint gak apa-apa?"

Kutipan tersebut di atas adalah jenis tindak tutur perlokusi karena apa yang disampaikan oleh guru menimbulkan suatu efek yang membuat siswa bereaksi. Jika dilihat dari penggunaan prinsip kesantunan dan kerja sama, maka kalimat di atas tidak mengandung pelanggaran.

6. Guru : "Kita akan bahas tugasnya minggu depan."

Siswa: Libur, Pak."

Kutipan tersebut di atas adalah jenis tindak tutur perlokusi karena apa yang disampaikan oleh guru menimbulkan suatu efek yang membuat siswa bereaksi. Jika dilihat dari penggunaan prinsip kesantunan dan kerja sama, maka kalimat di atas mengandung pelanggaran, yaitu melanggar prinsip kesantunan pada maksim pemufakatan. Artinya, siswa yang mengatakan libur tidak memaksimalkan kecocokan dengan apa yang disampaikan oleh gurunya. Selain itu, kalimat tersebut mengandung pelanggaran prinsip kerja sama pada maksim relevansi, yaitu apa yang disampaikan oleh siswa tersebut tidak sesuai dengan apa yang dinyatakan oleh guru.

7. Guru : "Bagaimana ceritanya?"

Siswa: "Kita tidak boleh sombong."

Guru : "Itu amanatnya."

Kutipan tersebut di atas adalah jenis tindak tutur perlokusi karena apa yang disampaikan oleh siswa menimbulkan suatu efek yang membuat guru bereaksi dari apa yang disampaikan oleh siswa tersebut. Jika dilihat dari penggunaan prinsip kesantunan dan kerja sama, maka percakapan di atas mengandung pelanggaran. Pelanggaran terjadi pada kalimat yang dinyatakan oleh siswa, yaitu pelanggaran prinsip kualitas dan relevansi, yakni siswa memberikan jawaban yang salah atas pertanyaan yang diajukan dan tidak sesuai dengan konteksnya. Guru mengharapkan komentar dari siswa tentang cerita yang dibacakan dalam hal isi ceritanya, bukan amanatnya.

8. Guru : "Siapa yang bisa menjawab akan saya beri nilai."

Siswa:(siswa berpikir untuk dapat menjawab pertanyaan guru)

Kutipan tersebut di atas adalah jenis tindak tutur perlokusi karena apa yang disampaikan oleh guru menimbulkan suatu efek yang membuat siswa bereaksi. Jika dilihat dari penggunaan prinsip kesantunan dan kerja sama, maka kalimat tersebut di atas tidak mengandung pelanggaran. 


\section{Penutup}

Berdasarkan pembahasan terhadap temuan penelitian dapat disimpulkan bahwa tindak tutur kaitannya dengan prinsip kesantunan dan kerja sama dalam pembelajaran bahasa Indonesia pada kelas VII SMP Kartika II-2 Bandar Lampung mengandung beberapa jenis tindak tutur. Pada jenis tindak tutur lokusi, guru sudah mampu menggunakannya ditandai dengan penggunaan kalimat yang lugas yang sifatnya informatif tanpa mengharapkan suatu tindakan dari siswanya. Selain itu, pada penggunaan jenis tindak tutur ini, guru sudah mampu menggunakan prinsip kesantunan dan kerja sama dengan baik karena berdasarkan hasil penelitian tidak ditemukan adanya pelanggaran penggunaan prinsip tersebut pada jenis tindak tutur ini.

Guru dan siswa juga sudah baik dalam menggunakan tindak tutur ilokusi. Hal ini terbukti dari hasil penelitian yang membahas bahwa kalimat-kalimat tuturan yang digunakan oleh guru dan siswa dalam mengutarakan maksud untuk mengharapkan suatu tindakan sudah digunakan dengan baik sehingga hal ini dapat mendukung proses pembelajaran yang akan meningkatkan keberhasilan tujuan pembelajaran. Selain itu, dalam tindak tutur ilokusi, penggunaan prinsip kesantuan dan kerja sama sudah baik. Hal ini terbukti sangat minimnya pelanggaran yang dilakukan oleh guru dan siswa.

Penggunaan jenis tindak tutur perlokusi yaitu tuturan yang digunakan untukmenimbulkan efek kepada petutur sudah digunakan oleh guru dan siswa dengan baik. Namun, penggunaan prinsip kesantunan dan kerja sama pada jenis tindak tutur ini perlu ditingkatkan karena pelanggaran yang dilakukan oleh guru dan siswa pada jenis tindak tutur ini lebih banyak dibandingkan dengan jenis tindak tutur lokusi dan ilokusi.

Berdasarkan tiga jenis tindak tutur yang dianalisis tersebut, guru dan siswa sudah cukup mampu menggunakan tindak tutur yang sesuai dengan prinsip kesantunan dan kerja sama. Hal ini terbukti dari kutipan-kutipan tuturan yang didapat hanya mengandung sedikit pelanggaran baik prinsip kesantunan maupun kerja sama.

\section{Daftar Pustaka}

Akhadiah, S. dkk. (1999). Teori Belajar Bahasa. Jakarta: Universitas Terbuka.

Alwi, H. dkk. (2003). Tata Bahasa Baku Bahasa Indonesia. Jakarta: Balai Pustaka.

Aminuddin (1990). Pengembangan Penelitian Kualitatif dalam Bidang Bahasa dan Sastra. Malang: Yayasan Asih Asah Asuh Malang.

Aslinda dan Syafyahya, L. (2007). Pengantar Sosiolinguistik. Bandung: PT. Refika Aditama.

Chaer, A. (2003). Psikolinguistik: Kajian Teoritik. Jakarta: PT. Rineka Cipta.

Chaer, A. (2006). Tata Bahasa Praktis Bahasa Indonesia. Jakarta: PT. Rineka Cipta.

Chaer, A. dan Agustina, L. (2004). Sosiolinguistik: Perkenalan Awal. Jakarta: PT. Rineka Cipta.

Darma, Y.A. (2009). Analisis Wacana Kritis. Bandung: Yrama Widya.

Dimyati dan Mudjiono. (1999). Belajar dan Pembelajaran. Jakarta: PT. Rineka Cipta.

Djajasudarma, F. (1994). Wacana: Pemahaman dan Hubungan Antarunsur. Bandung: Eresko.

Eriyanto (2009). Analisis Wacana: Pengantar Analisis Teks Media. Yogyakarta: LKIS Printing Cemerlang.

Grice, H.P. (1975). Logic and Coversation: Syntax and semantic, speech act. New York: Academic Press.

Gunarwan, A. (1994). “Kesantunan Negatif di Kalangan Dwibahasawan Indonesia-Jawa di Jakarta" dalam PELBA7. Jakarta: Unika Atmajaya Press.

Keraf, G. (2004). Komposisi. Flores: Nusa Indah.

Kushartanti dkk. (2008). Pesona Bahasa: Langkah Awal Memahami Linguistik. Jakarta: Gramedia Pustaka Utama. 
Leech, G. 1993. Prinsip-Prinsip Pragmatik. Jakarta: Universuty Press.

Nazir, M. (2005). Metode Penelitian. Bogor: Ghalia Indonesia.

Popham, J. dan Baker, E.L. (2005). Teknik Mengajar secara Sistematis (edt). Jakarta: PT. Rineka Cipta.

Rohmadi, M. (2004). Pragmatik: Teori dan Analisis. Yogyakarta: Lingkar Media.

Sudaryat, Y. (2008). Makna dalam Wacana: Prinsip-prinsip Semantik dan Pragmatik. Bandung: Yrama Widya.

Sugiyono (2006). Metode Penelitian Pendidikan: Pendekatan Kuantitatif, Kualitatif, dan R\&D. Bandung: Alfabeta. Sumiati dan Asra (2008). Metode Pembelajaran. Bandung: CV. Wacana Prima.
Surastina (2010). Psikolinguistik: Sebuah Pengantar. Yogyakarta: Paradigma Indonesia.

Surastina (2011). Pengantar Semantik dan Pragmatik. Yogyakarta: New Elmatera.

Syamsuddin A.R. (1992). Studi Wacana: Teori-Analisis Pengajaran. Bandung: FPBS IKIP Bandung.

Tarigan, H. G. (2009). Pengajaran Wacana. Bandung: Angkasa.

Wijana, D. P. (1996). Dasar-dasar Pragmatik. Yogyakarta: Andi Offset.

Wijana, D.P. dan Rohmadi, M. (2010). Analisis Wacana Pragmatik: Kajian Teori dan Analisis. Surakarta: Yuma Pustaka. 